\title{
A STUDY OF THE ANCIENT MORTARS IN THE NORTH TOWER OF PAMPLONA'S SAN CERNIN CHURCH
}

J.I. Alvarez*, I. Navarro, A. Martín and P.J. García Casado

Department of Chemistry and Soil Science, University of Navarra, 31080, Pamplona

(Spain)

$\mathbf{N}^{0}$ of pages: 27

$\mathbf{N}^{\circ}$ of tables: 10

Keywords: B. Characterization, D. Aggregate, D. $\mathrm{CaCO}_{3}, \mathrm{E}$. Mortar, B. Thermal analysis

Please, send all correspondence to:

Dr. José I. Alvarez-Galindo

Dpto. de Química y Edafología

Fac. de Ciencias

Universidad de Navarra

$\mathrm{C} /$ Irunlarrea $\mathrm{s} / \mathrm{n}$

31.080 Pamplona (Navarra)

Spain

Phone: 34948425600

Fax: 34948425649

E-mail: jalvarez@unav.es 


\title{
A STUDY OF THE ANCIENT MORTARS IN THE NORTH TOWER OF PAMPLONA'S SAN CERNIN CHURCH
}

\author{
J.I. Alvarez*, I. Navarro, A. Martín, and P.J. García Casado \\ Department of Chemistry and Soil Science, University of Navarra, 31080, Pamplona \\ (Spain)
}

\begin{abstract}
Different ancient mortar samples of Pamplona's San Cernin church have been analyzed to characterize their binder and aggregate fractions. A complete characterization has been carried out including chemical (rapid approximate analysis, soluble salts and trace elements, using traditional chemical procedures, ionic chromatography and spectrophotometry techniques), mineralogical-petrographic (structural characterization and X-ray diffraction) and thermal studies (simultaneous differential thermal and thermogravimetric analysis). These studies have permitted to establish that a type of lime mortar with silica aggregate was employed in the building of the tower. Three different classes of this type of mortar and their approximate original composition have been determined. Recommendations about the employment of new materials in a possible restoration are given.
\end{abstract}

Keywords: B. Characterization, D. Aggregate, D. $\mathrm{CaCO}_{3}$, E. Mortar, B. Thermal analysis 


\section{Introduction}

The Church of San Cernin is located in the ancient municipal heart of Pamplona and it is flanked by its so-called "North Tower". The church dates from the XIII century, with vestiges from the XII.

This study has realized a morphological examination of the samples (visually and using optical microscopy), a mineralogical study using DRX and rapid approximate chemical analysis, following the standards established in some previous studies [1-3]. The objective being the grouping and classification of the mortars, thus attempting to establish the constituent types. This was followed by a complete characterization (chemical: total composition, soluble salts, traces elements; mineralogical-petrographic: aggregate granulometric fractions, DRX; and thermal studies) with the purpose of characterizing the materials and their origin. The final conclusion being the approximate indication of the original make up of the materials and to establish standards for the employment of new materials in the process of restoration.

\section{Material and methods}

The sampling procedure for mortars has been carried out taking a part of the mortars with a chisel and throwing away the external portion of the joints, with the aim of obtaining non-altered material. The structural characterization was carried out using an optical macroscope (Wild M420) obtaining the results through a previously described specification [1]. The diffraction of X-rays was undertaken using a Siemens D-500 (Karlsruhe, Germany) Kristalloflex 810 diffractometer, according to the diffraction in powder method, with a $\mathrm{CuK}_{\mathrm{a} 1}$ radiation and a speed of 5\%/min, sweep 2 to 70, $2 \theta$.

The sample ground in an agate mortar is dried until constant weight in a heater and then $1 \mathrm{~g}$ of sample is taken for its subsequent analysis. The chemical study was carried out after attack with hot $\mathrm{HCl}$ 1:5 volume ratio (2 M) [3], followed by traditional chemical 
procedures. A titration with ethylenediaminetetraacetic acid (EDTA) (using murexide and eBT (eriochrome black T) as indicators) was used for the analysis of calcium and magnesium in the soluble fraction. The contents of soluble silica, Fe, and Al were determined by atomic emission spectroscopy with inductively coupled plasma (ICP) (Jobin Ybon JY 38S Plus Sequential, Instruments SA, France). When the amounts of $\mathrm{Fe}_{2} \mathrm{O}_{3}$ and $\mathrm{Al}_{2} \mathrm{O}_{3}$ were higher than $1 \%$, the determinations were carried out by titrations using barium diphenylaminosulphonate and ditizone as indicators. Sodium and potassium were determined by flame emission atomic spectroscopy (Perkin Elmer 460, Perkin Elmer, Überlingen, Germany). The contents of elements after an alkaline fusion of the samples were determined by traditional chemical methods. The anions were determined by ionic chromatography (chromatograph Dionex QIC Analyzer, Dionex, Idstein, Germany). Thermal studies were carried out using a simultaneous DTA-TGA Stanton-Redcroft STA-780.

A total of 24 mortar samples were studied, belonging to the various thirds of the tower and to the adjoining exteriorly accessed staircase (Fig. 1). At least three samples of each architectural zone were taken to assure representative results.

\section{Results and discussion}

\subsection{Classification of the mortars}

\subsubsection{Morphological study}

The bibliographical study undertaken [4] concluded that none of the restorations carried out in San Cernin had affected the North Tower mortars. The structural-morphological study, with the help of a magnifier and an optical macroscope, revealed the following mean results: in the $\mathrm{AZ}$ and $\mathrm{AD}$ zones, mortars of middle to low compactness, with finely crushed white aggregate, not very variable and with a high degree of insert in the matrix, and white binder. 
Zone B also presented similar characteristics with respect to the binder and to the aggregate. The mortars of zones TE and C frequently present splits and lumps in the binding, in zone $\mathrm{C}$ a darker superficial crust was common, with a different patina. The mortars of the TE zone contain beige binding. The aggregate was very small. The mortar defined was of quite different characteristics from those of the zones AZ, AD and B. It was also different to zone C, which had a clear beige binding, but contained a middle size aggregate which was quite heterogeneous.

\subsubsection{Mineralogical study}

The mean results of the mineralogical study using DRX, semi-quantitative, are reflected in Table 1.

In the tower of San Cernin, lime mortar was established to be the mortar type. Hexagonal calcite appears as the prevailing phase in most of the samples. Together with $\alpha$-quartz made up practically 70 to $90 \%$ of all the samples. Complex silicates were observed, probably from clay phases, whose determination has been complicated because:

a) the most intense diffraction peaks of most of these compounds appear within a narrow range, and generally the samples contain mixtures of those compounds in different proportions;

b) the small quantity usually present has meant that either the diffraction peaks may not have stood out sufficiently, or they may have been masked by the majority components.

The samples that contain plaster in small quantities could indicate the presence of this material as an additive with functions as indicated in the literature [5,6]. Alternatively, it could be evidence of sulphatation. The plaster shouldn't have been added at the same time as the limestone, nor part constitute of these mortars, since it could not have 
rehydrated to form $\mathrm{CaSO}_{4} \cdot 2 \mathrm{H}_{2} \mathrm{O}$, upon reaching temperatures around $1000^{\circ} \mathrm{C}$ in the calcination of the limestone.

The quantities of silicates found in the studied samples are very scarce. Such a very high burning point in the limestone materials implies that these compounds detected through DRX could only originate from aggregate added 'a posteriori' or an intentional addition, since at high temperatures most of the compounds of the clay phase (kaolinite and montmorillonite, for example) lose their crystalline structure [7]. The minuscule quantity present excludes intentional addition; therefore, it is probable that the clays present come from the added siliceous aggregate [8-10].

From the DRX study of the IR in acid, it can be concluded that the aggregate of the studied mortars is of a silica nature. More than $75 \%$ of its composition is $\alpha-\mathrm{SiO}_{2}$. It presents an important number of complex silicates in small quantity, the most frequent phases being muscovite, anorthite and albite.

\subsubsection{Rapid chemical analysis and classification}

The results of the chemical analysis with hot $\mathrm{HCl} \mathrm{1:5} \mathrm{volume} \mathrm{ratio} \mathrm{(Table} \mathrm{2)} \mathrm{have}$ allowed the grouping of the mortars, with the help of triangular graphs and of the relationship IR/SF (insoluble residue/soluble fraction). The 'outlier' values were eliminated from the results via an aberrant test employing the t of Student, giving a 99\% confidence level.

The results shows a good grouping of the samples of the zone AZ around the average value, the same occurs in the zones $\mathrm{AD}$ and $\mathrm{B}$ (adequate coefficients of variation). It is complicated, in a common representation of the three groups of samples, to establish a distinction since the areas of the three architectural zones overlap, even though it can be deduced that zone $\mathrm{AD}$ had a smaller percentage of $\mathrm{CaCO}_{3}$, but this does not seem sufficient to configure a different class of mortar. 
The zone TE is clearly different to the three previous zones, as zone C. This situation can be observed in the representation of the average values of the samples of each zone. The following figure represent the grouping of the average values of $\mathrm{CaCO}_{3}$, insoluble residue and soluble fraction analysis of the diverse architectural zones (Fig. 2).

The mean values of the relationship IR/SF obtained for each architectural zone studied in the tower of San Cernin are collected in Table 3. This parameter also makes possible discrimination among the zones previously indicated: the zones $\mathrm{TE}$ and $\mathrm{C}$ are differentiated between themselves and the others.

Through the application of these discrimination standards, the existence of a lime mortar with silica aggregate type of mortar in the tower of San Cernin has been established. Within this mortar, three different classes of lime mortars can be grouped into various architectural zones: MCB1 (zones AZ, AD and B), MCB2 (zone TE) and MCB3 (zone C).

Representative samples B13 (MCB1), TE19 (MCB2), C23 (MCB3) have been chosen of each class of mortar, whose mean values appear in the Table 4. The criteria followed have been: the state of aggregation and structure, the available quantity and the representativity on the set.

\subsection{Complete characterization of representative samples}

\subsubsection{Chemical study}

Chemical composition: Table 5 includes the results of the chemical analysis of the majority components of the three representative samples of the classes of mortars used in the tower of the Church of San Cernin. In Table 6 are the results of the chemical analysis of the solution (soluble fraction) after acid attack.

The representative sample MCB2 contains a high percentage of $\mathrm{MgO}$, this perhaps could be due to the utilization in this area of dolomites. In the same way, there is an 
increase in the contents in $\mathrm{SO}_{3}$ determined in the sample MCB2, indicating a material of different origin to the other two samples. This fact could be related to some high alkaline metal values ( $\mathrm{Na}$ especially), therefore the presence of this sort of soluble sulphate is probable. The percentages of soluble silica in acid are, as a rule, low therefore some hydraulic properties of the mixture are not expected [11]. This fact maintains the relationship with the low content determined in clays and hydraulic silicates.

Trace Elements: the chemical nature of the trace elements and their relative concentrations indicate the geological history of the material, in function of the parameters that have conditioned them [12,13]. Figure 3 shows the graphs of trace metals.

The critical study of these graphs indicates that there are not large differences in the composition of the trace metals analyzed among the mortars of the three studied classes. Therefore, it is probable that the materials used proceed from the same quarry. This is logical if one considers the size of the tower of the Church of San Cernin which was built, furthermore, in a continuous form.

The classes MCB1 and MCB3 have almost identical micro-chemical composition, their raw material proceeds from the same quarry and zone. This also is adjusted to the distribution found for the classes of mortars within the tower of the Church of San Cernin (MCB1, superior and center thirds of the tower; MCB3 inferior third). Air pollution could be the responsible for the high contents of lead.

Soluble salts: the results of total conductivity in the aqueous extract (Table 7) show a low conductivity in the analyzed mortars, something which supposes, with reference to the bibliographical data, a scarce total salinity [14]. Nevertheless, the sample MCB2 shows a more marked salinity. 
The contents in $\mathrm{Cl}^{-}$are very low in comparison to some studies (0.67-2.27\%) [14], even the sample MCB2 reaches limit values (0.06\%) [8]. Something similar occurs with the contents in nitrates, low as a rule and especially in the sample MCB2. The sulphates present low quantities in the samples MCB1 and MCB3, but present an important percentage in the MCB2.

It is observed with clarity that the materials used in the zone represented by MCB2 are very different from those of the other two zones, that are quite similar.

\subsubsection{Mineralogical-petrographic study}

The distribution characteristics of the grain size of the arid through a granulometric study have also been undertaken. They have configured the following cumulative granulometric distribution (Fig. 4-6).

It is observed that the clayey fraction $(<0.1 \mathrm{~mm})$ is very high in MCB2 (46\%), in comparison with MCB1 and MCB3. The fine sand fraction $(0.20-0.50 \mathrm{~mm})$ turns out to be, in MCB1 and MCB3 (65.06 and 73.03\%, respectively) in percentage terms, the most important fraction. In the intermediate sands $(1-1.6 \mathrm{~mm})$, large differences are not found, although MCB2 presents the smaller rejected percentages (4.28\%). In the bulk sands fraction (2-4 mm) MCB1 and MCB3 are around 7\% of rejection and 4.5\% for MCB2, being, in any event, percentages not very important.

Via the value of the median (Table 8) we find that the studied mortars have in their majority fine sand composition and especially the class MCB2. The $\mathrm{S}_{\mathrm{o}}$ (the quotient between the $3^{\text {rd }}$ and $1^{\text {st }}$ quartile expressed in $\mathrm{mm}$ ) shows a sand well selected (under $<$ 2.5) [15] for the classes MCB1 and MCB3, acceptable for their employment in mortars, while the aggregate used in MCB2 does not show an adequate scale in the grain sizes. It indicates that there is a manifest similarity among the aggregate of the classes MCB1 and MCB3 that permits the hypothesis that their origin was identical. 


\subsubsection{Thermal studies}

The examination of the simultaneous DTA-TGA curves obtained shows the endothermic peaks to be outstandingly associated with the decomposition of the calcite, and that they are associated in the three samples studied with the loss of bulk reflected in Table 9.

The high quantities of Mg found in MCB2 do not correspond, however, with the low percentages of loss between $550^{\circ}$ and $610^{\circ} \mathrm{C}$ (decarbonation of $\mathrm{MgCO}_{3}$ ), therefore it seems we could discard the presence of dolomite limestone. Furthermore, hydrolysis of the $\mathrm{MgCO}_{3}$ in the setting might have generated the compound hydromagnesite $\left(\mathrm{Mg}_{5}\left(\mathrm{CO}_{3}\right)_{4}(\mathrm{OH})_{2} \cdot 4 \mathrm{H}_{2} \mathrm{O}\right)$, that would show a loss of bulk in the TG curve between $220^{\circ}$ and $460^{\circ} \mathrm{C}$, and in the DTA curve three endothermic peaks, of $250^{\circ}, 384^{\circ}$ and $441^{\circ} \mathrm{C}$. These would be related to an initial hydration water loss, the first, and with the loss of water of hydration remaining and of ions $\mathrm{OH}^{-}$the other two [16-18]. This situation has not been observed in the thermal study of MCB2.

The existence of incomplete carbonation has not been proven in any of the three studied samples.

The observation of the percentages losses at different temperature ranges of the samples MCB1 and MCB3 notes an important similarity among both classes of mortars, something which would indicate a common source of raw material origin and a common elaboration recipe.

\section{Conclusions}

The greater part of the mortars studied in the tower of San Cernin are mortars with lime binder (they can be classified by the type of ordinary limes) and a silica aggregate. The hydraulic effect practically can be considered to be non-existent in these mortars. 
The relationship binder/aggregate determined in the classes of mortars responds to a normal quotient. The calculation of the initial weight percentages of raw materials has given the values collected in Table 10 for each class of mortar. The formulas used to calculate these percentages are showed as follows (Eq. 1-3). They are based in a previous study with slight modifications [19].

$$
\% \mathrm{Ca}(\mathrm{OH})_{2}=\frac{\frac{\mathrm{A}}{1,351}}{100-\left[\mathrm{A}-\frac{\mathrm{A}}{1,351}\right]} 100=\frac{\frac{\mathrm{A}}{1,351}}{100-[0,260 \mathrm{~A}]} 100(\mathrm{Eq} .1)
$$

where $\mathrm{A}$ is $\% \mathrm{CaCO}_{3}$ calculated in TG curve (endothermic peak between $610^{\circ}$ and $880^{\circ} \mathrm{C}$, associated with $\mathrm{CO}_{2}$ loss) (Table 9).

$$
\text { \%Aggregate }=\frac{\% \text { IR }}{100-\left[\mathrm{A}-\frac{\mathrm{A}}{1,351}\right]} 100=\frac{\% \mathrm{IR}}{100-[0,260 \mathrm{~A}]} 100 \text { (Eq. 2) }
$$

where IR is the insoluble residue calculated in the chemical analysis (Table 4)

$$
\% \text { Water }=100-\left[\% \mathrm{Ca}(\mathrm{OH})_{2}+\% \text { Aggregate }\right](\mathrm{Eq} .3)
$$

The class MCB2 is very interesting by having a relationship binder/aggregate 1:1 in weight in its initial composition. In the case of this class there remain without confirmation some interesting aspects that perhaps modify in some aspect these considerations, such as the high quantities of sulphates and of magnesium. Even though the quantities of sulphates can be due to alkalines sulphates, it has not been able to specified the chemical compound of the magnesium present.

The conservation state seems good, somewhat worse in MCB2, that possesses a greater value of total conductivity (soluble salts) and that has a higher risk of deterioration by disintegration.

MCB1 and MCB3 maintain a very important similarity with reference to the origin of the raw material, and their differences can be due to not very significant variations in 
the recipes. On their employment in reconstruction, we incline for a mortar akin to that of the class MCB1, with a relationship binder/aggregate adequate (higher than that of MCB3) and without the problems of MCB2 (bad distribution of the aggregate and high quantity of soluble sulphates).

\section{References}

[1] J.I. Alvarez, A. Martín, P.J. García Casado, Méthodologie employée dans la caractérisation de mortiers de la Cathédrale de Pampelune (Espagne), in: 8th Congress International on Deterioration and Conservation of Stone, Josef Riederer (Ed.), Berlin, 3 (1996), pp.1457-1470

[2] J.I. Alvarez, A. Martín, P.J. García Casado, Propuesta de una metodología analítica de caracterización de morteros antiguos, in: 26a Reunión Bienal de la Real Sociedad Española de Química, César Mira (Ed.), Cádiz, 2 (1997), pp.645-647

[3] J.I. Alvarez, A. Martín, P.J. García Casado, I. Navarro, A. Zornoza. Methodology and validation of a hot hydrochloric acid attack for the characterization of ancient mortars. Cem Concr Res 29 (7) (1999) 1061-1065

[4] M.C. García Gaínza, Catálogo Monumental de Navarra, Departamento de Educación y Cultura, Institución Príncipe de Viana (Gobierno de Navarra) (Ed.) (1997), pp.109-143

[5] G. Martinet, F.. Deloye, J.C. Golvin, Caractérisation des mortiers pharaoniques du Temple d'Amon à Karnak. Bull liaison Labo P et Ch 181 (1992) 39-45

[6] J. Ashurst, Mortars, plasters and renders in conservation, Ecclesiastical Architect's and Surveyors'Association (Ed.) (1983), pp.16-18

[7] T. Kawiak, Gypsum mortars from a twelfth-century church in Wislica, Poland, Studies in Conservation 36 (1991) 142-150

[8] M.T. Blanco-Varela, F .Puertas, A .Macías, A. Palomo, Study of support romain mortars of Italica's mosaics, in: 7th International Congress on Deterioration and Conservation of Stone, J.Delgado Rodrigues, Fernando Henriques, F. Telmo Jeremias (Eds.), Lisbon, 3 (1992), pp.1299-1305

[9] S.L. Sarkar, Microstructural investigation of renaissance mortar from Montreal, Quebec, Canada, Cem Concr Res 22 (1992) 1011-1018

[10] B. Marchese, V. Garzillo, An investigation of the mosaics in the cathedral of Salerno. Part I. Characterization of binding materials, Studies in Conservation 28 (1983) 127-132

[11] F.X. Deloye, Le calcul minéralogique. Application aux monuments anciens, Bull liaison Lab P et Ch 175 (1991) 59-65

[12] M.A. Bello, A. Martín, Microchemical characterization of building stone from Seville cathedral, Spain, Archaeometry 34 (1) (1992) 21-29

[13] M.J. De la Torre, J. Rodríguez, E.M. Sebastián, Caracterización geoquímica de morteros y hormigones hispanomusulmanes. Procedencia de materias primas, in: IV Congreso de geoquímica de España, CEDEX (Ed.), Soria (1991), pp.470-478

[14] G. Alessandrini, R. Bugini, R. Negrotti, L. Toniolo, Characterization of plasters from the church of San Niccolò di Comelico (Belluno- Nothern Italy), Eur J Mineral 3 (1991) 619-627 
[15] M. Frizot, Mortiers et enduits peints antiques- étude technique et archéologique, Centre de Recherches sur les techniques gréco-romains, Université de Dijon (Ed.) (1975) 57-137

[16] C. Fiori, M. Macchiarola, Study of traditional mortars and plasters using thermoanalyses, in: III Congreso Internacional de Rehabilitación del Patrimonio Arquitectónico y Edificación, E.M. Sebastián Pardo, I. Valverde Espinosa, U. Zezza (Eds.), Granada (1996), pp.223-237

[17] S. Bruni, F. Cariati, P. Fermo, A. Pozzi, L. Toniolo, Characterization of ancient magnesian mortars coming from northern Italy, Termochim Acta 321 (1998) 161165

[18] A. Bakolas, G. Biscontin, A. Moropoulou, E. Zendri, Characterization of structural byzantine mortars by thermogravimetric analysis, Termochim Acta 321 (1998) 151160

[19] G. Alessandrini, R. Bugini, L. Folli, M. Realini, L. Toniolo, The compositional ratios of mortars. Comparison between chemical and petrographical methods in: 7th International Congress on Deterioration and Conservation of Stone, J.Delgado Rodrigues, Fernando Henriques, F. Telmo Jeremias (Eds.), Lisbon, 2 (1992), pp.667-675 
Table 1. Results of X-ray diffraction in original mortar sample.

\begin{tabular}{||c||c|c|c|c|c||}
\hline \hline Sample & Calcite & $\begin{array}{c}\text { Silica } \\
\left(\alpha-\mathrm{SiO}_{2}\right)\end{array}$ & $\begin{array}{c}\text { Gypsum } \\
\left(\mathrm{CaSO}_{\mathbf{4}} \cdot \mathbf{2 H}_{2} \mathbf{O}\right)\end{array}$ & $\begin{array}{c}\text { Anhydrite } \\
\left(\mathrm{CaSO}_{4}\right)\end{array}$ & Silicates \\
\hline \hline AZ & $* *$ & $*$ & - & - & $\mathrm{t}$ \\
\hline AD & $* *$ & $*$ & - & - & - \\
\hline B & $* *$ & $*$ & - & - & - \\
\hline TE & $* *$ & $*$ & $\mathrm{t}$ & - & - \\
\hline C & $* *$ & $*$ & - & - & - \\
\hline
\end{tabular}

***: >75\%; **: 40\%-75\%; *: 20\%-40\%; p: small quantity (5-20\%); t: traces (<5\%); -: absent

Table 2. Results of the rapid chemical analysis in original sample of dry mortar. Average values in percentages for the various zones

\begin{tabular}{|c|c|c|c|c|c|c|c|c|c|c|c|c|}
\hline \multirow[t]{2}{*}{ ZONE } & \multicolumn{4}{|c|}{$\mathrm{CaCO}_{3}$} & \multicolumn{4}{|c|}{ Insoluble Residue (IR) } & \multicolumn{4}{|c|}{ Soluble Fraction (SF) } \\
\hline & $\overline{\bar{X}(\%)}$ & $\overline{\mathrm{n}}$ & S.D. & C.V. & $\mathrm{X}(\mathbf{\%})$ & 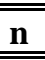 & S.D. & C.V. & $\overline{X(\%)}$ & $\overline{\mathrm{n}}$ & S.D. & C.V. \\
\hline $\mathbf{A Z}$ & 55.11 & 7 & 3.63 & 6.60 & 33.10 & 7 & 3.02 & 9.13 & 11.79 & 7 & 1.84 & 15.64 \\
\hline AD & 49.10 & 3 & 1.31 & 2.66 & 34.33 & 3 & 2.91 & 8.47 & 16.57 & 3 & 2.27 & 13.71 \\
\hline B & 55.11 & 3 & 1.60 & 2.90 & 30.94 & 3 & 0.26 & 0.85 & 13.95 & 3 & 1.72 & 12.36 \\
\hline TE & 52.94 & 3 & 1.54 & 2.91 & 44.62 & 3 & 1.77 & 3.97 & 2.45 & 3 & 0.33 & 13.58 \\
\hline C & 57.86 & 6 & 2.23 & 3.85 & 37.95 & 6 & 2.78 & 7.33 & 4.19 & 6 & 2.79 & 66.6 \\
\hline
\end{tabular}

X: average; n: population; S.D.: standard deviation; C.V.: coefficient of variation

Table 3. Average values of the relationship IR/SF

\begin{tabular}{|c|c|}
\hline Zone & Relation IR/SF \\
\hline \hline AZ & 2.87 \\
\hline AD & 2.11 \\
\hline B & 2.24 \\
\hline TE & 18.49 \\
\hline C & 14.41 \\
\hline
\end{tabular}


Table 4. Representative samples and mean values of each class of mortars of SF, IR and $\mathrm{CaCO}_{3}$

\begin{tabular}{||c||c|c|c||}
\hline Sample & B13 & TE19 & C23 \\
\hline \hline SF (\%) & 14.84 & 2.83 & 2.16 \\
\hline IR (\%) & 31.10 & 43.17 & 40.47 \\
\hline CaCO $_{\mathbf{3}}(\%)$ & 54.06 & 54.00 & 57.38 \\
\hline \hline Class & MCB1 & MCB2 & MCB3 \\
\hline \hline SF (\%) & 13.39 & 2.45 & 4.19 \\
\hline IR (\%) & 32.89 & 44.62 & 37.95 \\
\hline CaCO $_{3}(\%)$ & 53.72 & 52.94 & 57.86 \\
\hline \hline
\end{tabular}

Percentages related to original dry mortar

Table 5. Complete chemical analysis of the samples

\begin{tabular}{||c||c|c|c|c|c|c|c|c||}
\hline \hline Sample & Loss $^{\mathbf{a}}$ & $\begin{array}{c}\mathrm{SiO}_{\mathbf{2}}^{\mathbf{b}} \\
\mathbf{( \% )}\end{array}$ & $\begin{array}{c}\mathbf{C a O} \\
\mathbf{( \% )}\end{array}$ & $\begin{array}{c}\mathbf{M g O} \\
\mathbf{( \% )}\end{array}$ & $\begin{array}{c}\mathbf{R}_{\mathbf{2}} \mathbf{O}_{\mathbf{3}}{ }^{\mathbf{c}} \\
\mathbf{( \% )}\end{array}$ & $\begin{array}{c}\mathbf{S O}_{3} \\
\mathbf{( \% )}\end{array}$ & $\begin{array}{c}\mathbf{N a}_{\mathbf{2}} \mathbf{O} \\
\mathbf{( \% )}\end{array}$ & $\begin{array}{c}\mathbf{K}_{\mathbf{2}} \mathbf{O} \\
\mathbf{( \% )}\end{array}$ \\
\hline \hline MCB1 & 30.21 & 28.24 & 34.75 & 1.23 & 6.05 & 0.55 & 0.25 & 0.44 \\
\hline MCB2 & 28.06 & 25.57 & 24.41 & 7.01 & 4.46 & 4.15 & 4.99 & 1.45 \\
\hline MCB3 & 25.43 & 36.46 & 29.27 & 0.65 & 7.31 & 0.98 & 0.20 & 0.47 \\
\hline
\end{tabular}

Sodium carbonate-borax alkaline flux

Percentages related to original dry mortar

${ }^{\text {a }}$ Loss indicates the loss due to calcination at $975-1000^{\circ} \mathrm{C}$

${ }^{\mathrm{b}}$ The percentage of $\mathrm{SiO}_{2}$ refers to the total silica in the sample

${ }^{c} \mathrm{R}_{2} \mathrm{O}_{3}$ expresses the \% of $\mathrm{Fe}, \mathrm{Al}$ y Ti as oxides

Table 6. Chemical analysis of the soluble fraction

\begin{tabular}{||c||c|c|c|c|c|c|c||}
\hline \hline Sample & $\begin{array}{c}\mathrm{SiO}_{\mathbf{2}}{ }^{\mathrm{a}} \\
\mathbf{( \% )}\end{array}$ & $\begin{array}{c}\mathbf{C a O} \\
\mathbf{( \% )}\end{array}$ & $\begin{array}{c}\mathbf{M g O} \\
\mathbf{( \% )}\end{array}$ & $\begin{array}{c}\mathbf{F e}_{2} \mathbf{O}_{3} \\
(\mathbf{\% )}\end{array}$ & $\begin{array}{c}\mathrm{Al}_{\mathbf{2}} \mathbf{O}_{3} \\
\mathbf{( \% )}\end{array}$ & $\begin{array}{c}\mathbf{N a}_{2} \mathbf{O} \\
\mathbf{( \% )}\end{array}$ & $\begin{array}{c}\mathbf{K}_{\mathbf{2}} \mathbf{O} \\
\mathbf{( \% )}\end{array}$ \\
\hline \hline MCB1 & 1.01 & 35.00 & 2.80 & 1.59 & 0.91 & 0.089 & 0.069 \\
\hline MCB2 & 0.62 & 19.18 & 7.83 & 0.50 & 0.60 & 1.254 & 0.513 \\
\hline MCB3 & 1.05 & 31.62 & 1.76 & 1.05 & 1.28 & 0.099 & 0.133 \\
\hline
\end{tabular}

Percentages related to original dry mortar

${ }^{\text {a }}$ The percentage of $\mathrm{SiO}_{2}$ refers to the soluble silica in acid 
Table 7. Conductivity and anionic concentrations in the aqueous extract

\begin{tabular}{||c||c|c|c|c||}
\hline Sample & $\mathbf{C l}^{-} \mathbf{( \% )}$ & $\mathbf{N O}_{\mathbf{3}}{ }^{-} \mathbf{( \% )}$ & $\mathbf{S O}_{\mathbf{4}}{ }^{2-} \mathbf{( \% )}$ & $\begin{array}{c}\text { Conductivity for } \\
\mathbf{1} \mathbf{~ m g ~ o f ~ s a m p l e ~} \\
\text { for } \mathbf{~ m L ~}(\boldsymbol{\mu S})\end{array}$ \\
\hline \hline MCB1 & 0.250 & 0.338 & 0.158 & 23.26 \\
\hline MCB2 & 0.070 & 0.045 & 1.579 & 51.41 \\
\hline MCB3 & 0.180 & 0.121 & 0.151 & 17.84 \\
\hline
\end{tabular}

Percentages related to original dry mortar

Table 8. Median and So

\begin{tabular}{||c||c|c||}
\hline Representative Mortar & Median & S $_{\mathbf{o}}$ (sorting-index) \\
\hline \hline MCB1 & 0.210 & 2.21 \\
\hline MCB2 & 0.115 & 3.19 \\
\hline MCB3 & 0.220 & 2.48 \\
\hline
\end{tabular}

Table 9. Thermogravimetric analysis: peaks and associated losses

\begin{tabular}{||c||c|c|c|c||}
\hline Sample & $\begin{array}{c}\text { Endothermic } \\
\text { peak }\end{array}$ & $\begin{array}{c}\text { initial } \\
\text { sample \% }\end{array}$ & $\begin{array}{c}\text { final } \\
\text { sample \% }\end{array}$ & $\begin{array}{c}\text { \% sample } \\
\text { loss }\end{array}$ \\
\hline \hline \multirow{4}{*}{ MCB1 } & $20^{\circ}-120^{\circ}$ & 100 & 98.914 & 1.151 \\
\cline { 2 - 5 } & $300^{\circ}-550^{\circ}$ & 97.741 & 94.786 & 2.955 \\
\cline { 2 - 5 } & $550^{\circ}-610^{\circ}$ & 94.786 & 93.200 & 1.586 \\
\cline { 2 - 5 } & $390^{\circ}-585^{\circ}$ & 97.067 & 93.917 & 3.150 \\
\cline { 2 - 5 } & $610^{\circ}-880^{\circ}$ & 93.200 & 71.280 & 21.920 \\
\hline \hline \multirow{5}{*}{ MCB2 } & $20^{\circ}-120^{\circ}$ & 100 & 99.486 & 0.514 \\
\cline { 2 - 5 } & $300^{\circ}-550^{\circ}$ & 98.547 & 96.244 & 2.303 \\
\cline { 2 - 5 } & $550^{\circ}-610^{\circ}$ & 96.244 & 95.149 & 1.095 \\
\cline { 2 - 5 } & $390^{\circ}-585^{\circ}$ & 97.697 & 95.752 & 1.945 \\
\cline { 2 - 5 } & $610^{\circ}-880^{\circ}$ & 95.149 & 69.998 & 25.151 \\
\hline \hline \multirow{5}{*}{ MCB3 } & $20^{\circ}-120^{\circ}$ & 100 & 98.921 & 1.164 \\
\cline { 2 - 5 } & $300^{\circ}-550^{\circ}$ & 98.243 & 95.090 & 3.153 \\
\cline { 2 - 5 } & $550^{\circ}-610^{\circ}$ & 95.090 & 93.799 & 1.291 \\
\cline { 2 - 5 } & $390^{\circ}-585^{\circ}$ & 97.714 & 94.370 & 3.344 \\
\cline { 2 - 5 } & $610^{\circ}-880^{\circ}$ & 93.799 & 72.889 & 20.910 \\
\hline
\end{tabular}


Table 10. Approximate original composition of the classes of mortars (weight percentages)

\begin{tabular}{||c||c|c|c|c||}
\hline Class & $\begin{array}{c}\mathbf{C a}(\mathbf{O H})_{\mathbf{2}} \\
\mathbf{( \% )}\end{array}$ & $\begin{array}{c}\text { Aggregate } \\
\mathbf{( \% )}\end{array}$ & $\begin{array}{c}\text { Water of } \\
\text { constitution } \\
\mathbf{( \% )}\end{array}$ & $\begin{array}{c}\text { Relation } \\
\text { Binder- } \\
\text { aggregate }\end{array}$ \\
\hline \hline MCB1 & 42.35 & 35.73 & 21.92 & 1.18 \\
\hline MCB2 & 49.68 & 50.01 & 0.31 & 1.00 \\
\hline MCB3 & 40.13 & 46.17 & 13.70 & 0.87 \\
\hline
\end{tabular}

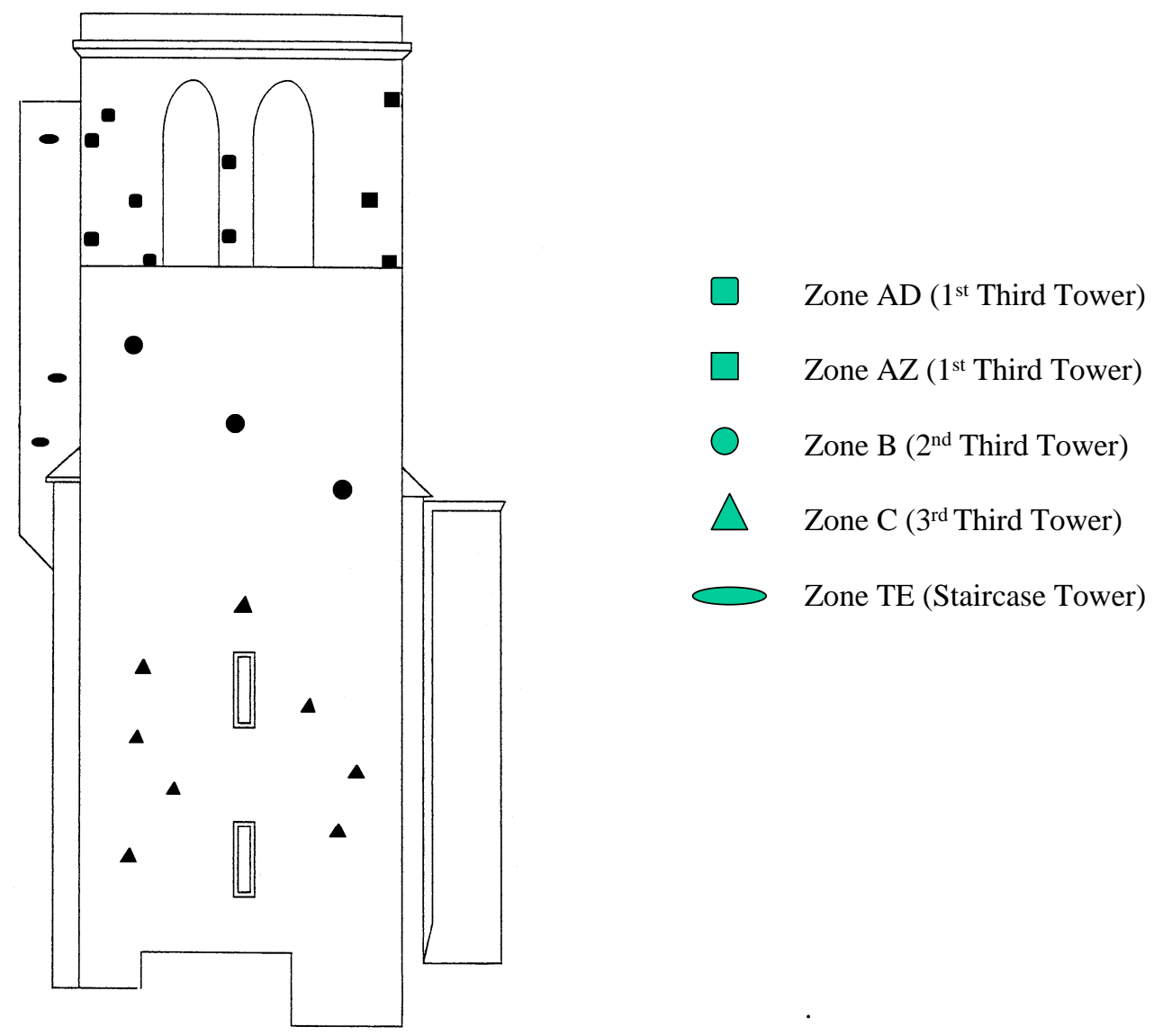

Figure 1. Areas of sampling in the North Tower of San Cernin Church 


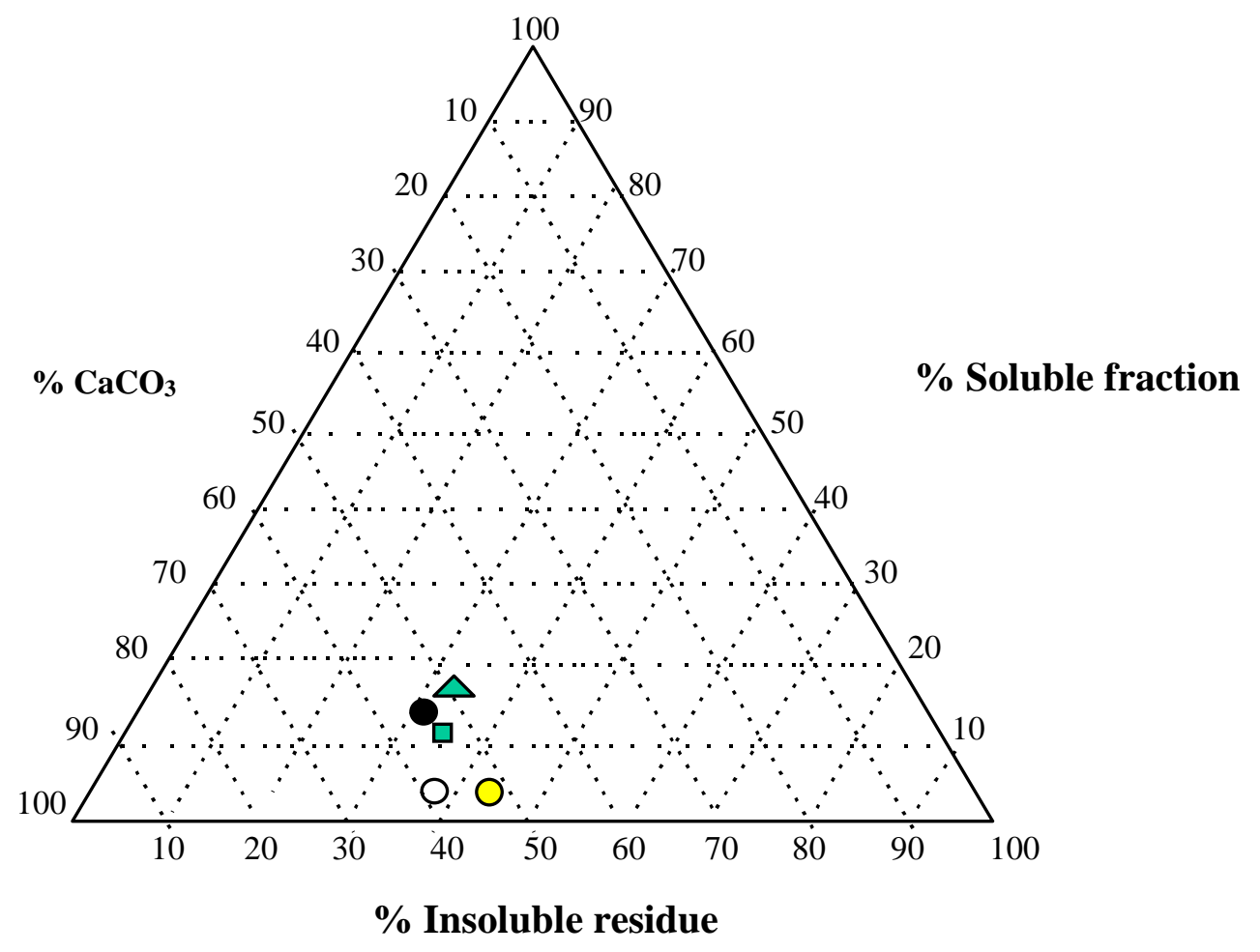

$\begin{array}{lllll}\square & \text { AZ } & \bigcirc & B & O \\ \triangle & \text { AD } & \bigcirc & \text { TE } & \end{array}$

Figure 2. Triangular Diagram. Average Values

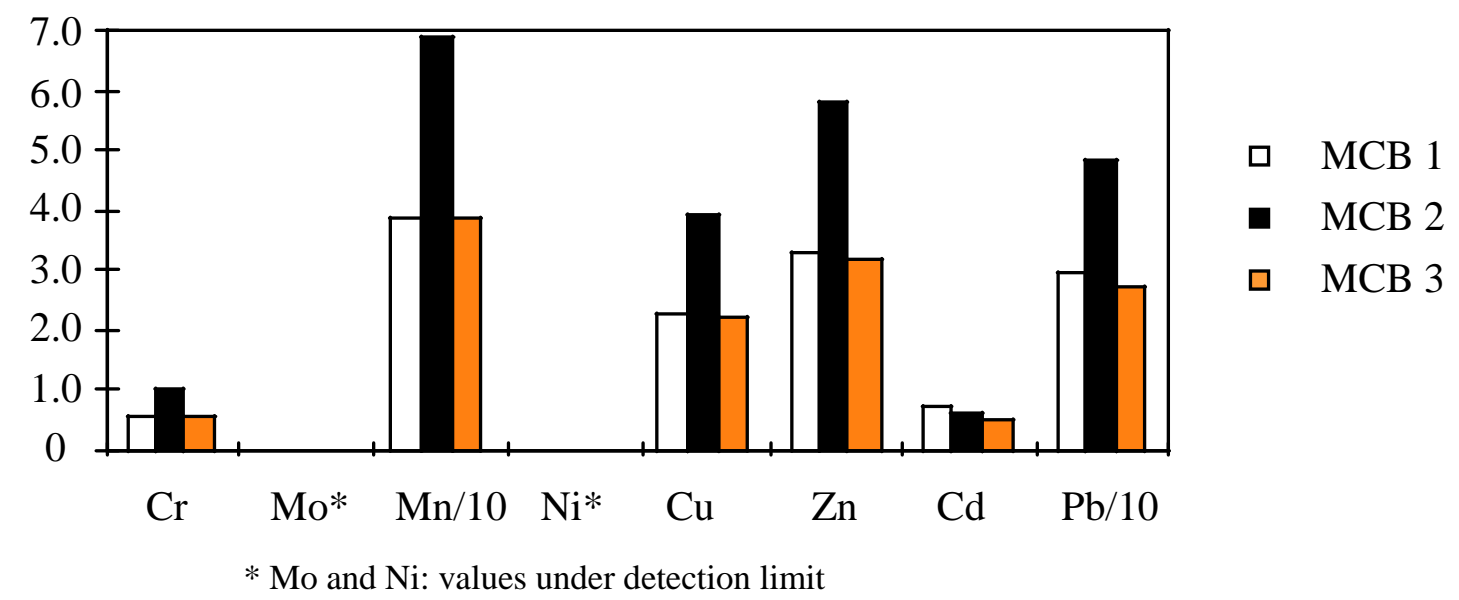

Figure 3. Diagrams in trace elements in representative mortars ( $\mu$ g trace element/g dry sample) 


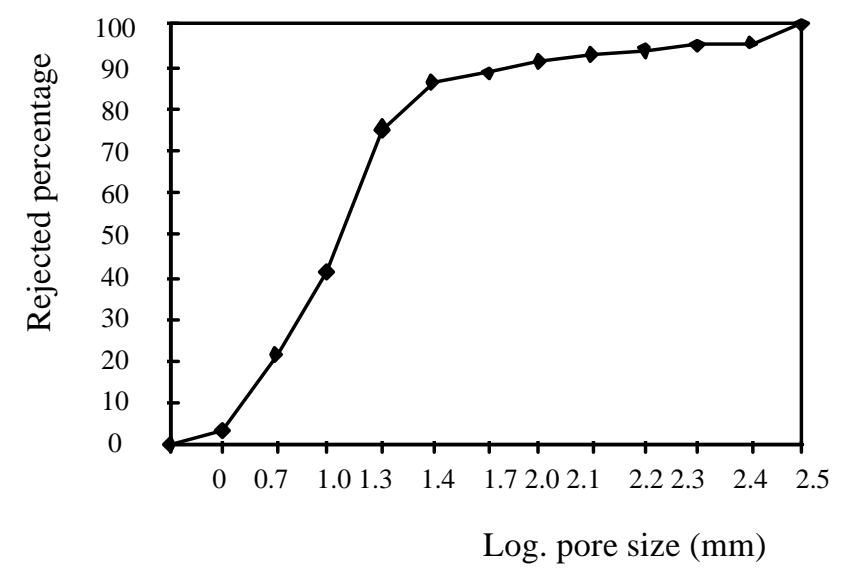

Figure 4. Granulometric curve MCB1

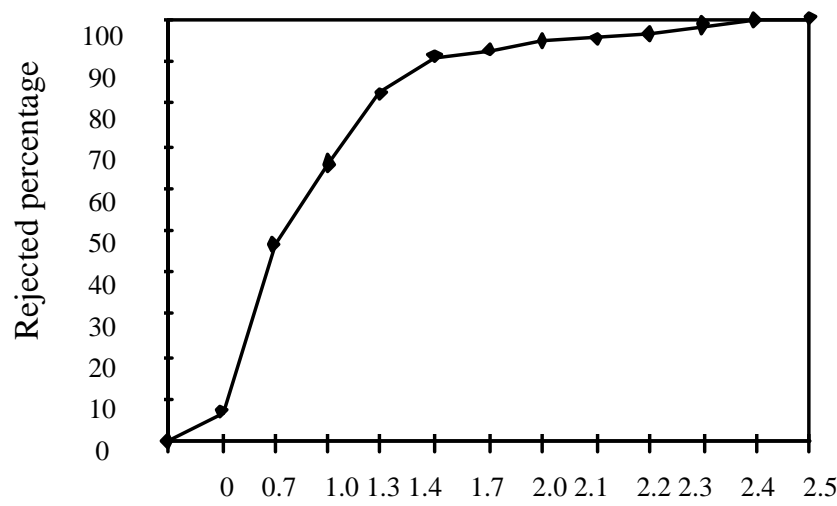

Log. pore size (mm)

Figure 5. Granulometric curve MCB2

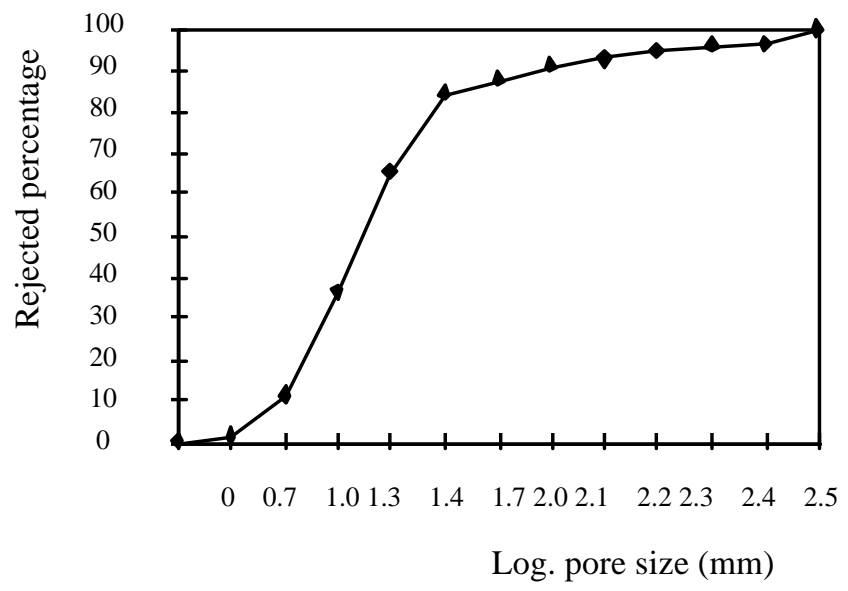

Figure 6. Granulometric curve MCB3 